\title{
Immunoreactive properties of pea protein extract and its trypsin hydrolysates*
}

\author{
R.J. Frączek ${ }^{1}$, E. Kostyra ${ }^{1}$, H. Kostyra ${ }^{2,3}$ and S. Krawczuk ${ }^{1}$ \\ ${ }^{1}$ Faculty of Biology, Chair of Biochemistry, Warmia and Mazury University \\ Oczapowskiego 1A, 10-957 Olsztyn, Poland \\ ${ }^{2}$ Institute of Animal Reproduction and Food Research, \\ Polish Academy of Sciences \\ Tuwima 10, 10-747 Olsztyn, Poland
}

(Received 31 August 2006; revised version 14 June 2007; accepted 6 September 2007)

\begin{abstract}
The study was undertaken to examine the immunogenic potential of pea protein of Polish variety Rodan and its trypsin hydrolysates differing in degree of hydrolysis. The physicochemical characteristic of pea protein extract and its hydrolysates, DH 2.0 and 5.0, were determined by SDS-PAGE electrophoresis, chromatofocusing, affinity chromatography, and sequential analysis. The immunogenic properties of pea protein and its trypsin hydrolysates, DH 2.0 and 5.0, were investigated by direct and competitive ELISA methods. The results confirmed that protein extract is a stronger immunogen than hydrolysates, while hydrolysate DH 2.0 was a stronger immunogen than DH 5.0. The dominant antigen isolated from pea protein extract and both trypsin hydrolysates had a molecular weight of about $20 \mathrm{kDa}$ and was in the glycoprotein fraction. The $\mathrm{N}$-terminal sequence of this antigen was determined to be: Thr-Glu-Thr-Thr-Ser-Phe-Leu-Ile-Thr-Lys-.
\end{abstract}

KEY WORDS: pea protein, immunonogenic properties, glycoproteins

\section{INTRODUCTION}

Pea seeds contain about $20-25 \%$ protein, depending on the variety. The majority of pea proteins consists of salt-soluble globulins, or storage proteins,

\footnotetext{
${ }^{*}$ Supported by the State Committee for Scientific Research, Grant No. PBZ-KBN-097/PO6/2003

${ }^{3}$ Corresponding author: e-mail: kos@pan.olsztyn.pl
} 
that are synthesized during seed development, stored in protein bodies, and hydrolysed during germination to provide nitrogen and carbon skeletons for the developing seedling (Wang et al., 2003). The remainder are albumins that include many housekeeping proteins, lectins, and lipooxygenases. From the nutritional point of view, globulins are very important; they consist of two classes, $7 \mathrm{~S}$ and $11 \mathrm{~S}$, based on their sedimentation coefficients. These proteins determine not only the nutritional value of peas for humans and animals, but also the immunogenic and allergenic potential of pea proteins (Hayakawa et al., 1999; Wensing et al., 2003). Before consumption by humans, pea seeds are thermally processed. This provides many benefits, but also brings about changes in allergenicity. It is necessary to recognize the full immunogenic potential of pea proteins in order to devise effective methods of reducing pea allergenicity. In particular, there is little information about the allergenic properties of glycoproteins. The authors hypothesise that many glycoproteins have not only allergenic properties, but can also undergo non-enzymatic glycosylation and be a source of neoallergens. Investigations of the immunogenic potential of protein enzymatic hydrolysates are also important from the practical point of view, because the hydrolysates usually have lower allergenic properties.

A study was undertaken to examine the immunogenic potential of pea protein isolated from the Polish pea variety, cv. Rodan.

\section{MATERIAL AND METHODS}

Pea seeds of the Polish variety, cv. Rodan, were purchased from the Breeding and Seed Gardening Production Plant (Nochow, Poland) and the Plant Breeding Company (Lagiewniki, Poland).

Extraction of proteins. Pea proteins were extracted by McLeester's method (1973). $9.1 \mathrm{~g}$ of pea flour were suspended in $25 \mathrm{ml}$ of buffer $(0.5 \mathrm{M} \mathrm{NaCl}$ and $0.25 \mathrm{M}$ ascorbic acid, $\mathrm{pH} 2.5$ ) and homogenized for $5 \mathrm{~min}$ at room temperature. Proteins were extracted for $1 \mathrm{~h}$ at $5^{\circ} \mathrm{C}$. The mixture was centrifuged at $30000 \mathrm{~g}$ for $30 \mathrm{~min}$ at $4^{\circ} \mathrm{C}$. The supernatant was dialysed for $48 \mathrm{~h}$ at $5^{\circ} \mathrm{C}$ against distilled water and then lyophilized. The protein content in the extract was determined by the Bradford and Kjeldahl methods (Bradford, 1976; AOAC, 1984).

Enzymatic hydrolysis of protein. A solution of protein extract $(3.57 \mathrm{~g} / 32 \mathrm{ml} 0.2$ $\mathrm{M}$ phosphate buffer, $\mathrm{pH} 8.0$ ) was prepared and heated to $50^{\circ} \mathrm{C}$. Then $0.022 \mathrm{~g}$ of trypsin $(15 \mathrm{mAU} / \mathrm{g}$ of extract) dissolved in $3.7 \mathrm{ml}$ of phosphate buffer was added and the solution mixed. Enzymatic hydrolysis was performed at $50^{\circ} \mathrm{C}$ and kept at $\mathrm{pH} 8.0$ by constant addition of a $1 \mathrm{M} \mathrm{NaOH}$ solution. Samples were taken after 0 , $10,20,30,60$ and $120 \mathrm{~min}$ of incubation. To a $5 \mathrm{ml}$ aliquot of the hydrolysate, $5 \mathrm{ml}$ of a $1 \%$ sodium dodecyl sulphate (SDS) solution were added and the mixture was 
heated at $90^{\circ} \mathrm{C}$ for $15 \mathrm{~min}$ to inactivate the enzyme. The final volume was adjusted to $25 \mathrm{ml}$. This solution will be referred to as "the examined sample". The degree of hydrolysis (DH) of the extract was determined by the TNBS method.

TNBS assay was performed according to Adler-Nissen (1979) with the reagent volume being reduced to $50 \%$ of the original volume. In brief, to a $0.125 \mathrm{ml}$ aliquot of the sample diluted 2.5 -fold, $1 \mathrm{ml}$ of a phosphate buffer $(\mathrm{pH} \mathrm{8.2,0.212} \mathrm{M)}$ was added along with $1 \mathrm{ml}$ of a freshly prepared aqueous solution of TNBS $(0.1 \%)$. Tubes were shaken in the dark at $50^{\circ} \mathrm{C}$ for $1 \mathrm{~h}$. The reaction was stopped by the addition of $2 \mathrm{ml}$ of a $100 \mathrm{mM} \mathrm{HCl}$ solution. After $20 \mathrm{~min} 4 \mathrm{ml}$ of water was added and after another $10 \mathrm{~min}$ the absorbance was read at $340 \mathrm{~nm}$. The blank was prepared identically and L-leucine was used as the standard (0-5 x 10-7 mol/ $/ 0.125$ $\mathrm{ml}$ of sample).

The total content of $\alpha$-amine groups ( $\mathrm{h} /$ total) was determined according to Hajos et al. (1988). A solution of $0.5 \mathrm{~g}$ of protein extract in $10 \mathrm{ml}$ of $6 \mathrm{M} \mathrm{HCl}$ was placed in a glass ampoule, saturated with nitrogen and closed. Hydrolysis was conducted at $105^{\circ} \mathrm{C}$ for $12 \mathrm{~h}$. The solution was filtrated, neutralized with $6 \mathrm{M} \mathrm{NaOH}$, and adjusted with phosphate buffer ( $\mathrm{pH}$ 8.2) to a final volume of $100 \mathrm{ml}$. The content of $\alpha$-amine groups was determined by the TNBS method (Adler-Nissen, 1979). The degree of hydrolysis (DH) was computed from the following equation (Adler-Nissen, 1979):

$$
\mathrm{DH}(\%)=\mathrm{h} / \mathrm{htotal} \times 100
$$

where: $\mathrm{h}$ - number of the hydrolysed peptide bonds ( $\mathrm{mEq} \mathrm{Leu}-\mathrm{NH}_{2} / \mathrm{g}$ of protein); htotal - total number of peptide bonds in the protein (mEq Leu - NH2/g of protein). Two tryptic hydrolysates, DH 2.0 and DH 5.0 were prepared.

Antibodies. Antibodies were produced using six rabbits. Immunogene prepared for the first immunization contained $0.5 \mathrm{ml}$ of antigen $(1.5 \mathrm{mg}$ of pea protein extract or its tryptic hydrolysates, DH 2.0 and 5.0) solution in $0.9 \%$ sodium chloride $(2.0 \mathrm{mg} / \mathrm{ml})$ emulsified with the equivalent of Freud's complete adjuvant (F 5881, Sigma, Poznań, Poland). Next, four immunizations were made at weekly intervals in the presence of Freud's incomplete adjuvant ( $F$ 5506, Sigma, Poznań, Poland) with the same volume and antigen concentration as described previously. All immunization injections were given subcutaneously. The production of antibodies and an increase in their titer were controlled using the indirect ELISA method by taking blood samples from the marginal vein of a rabbit 2-3 days prior to the subsequent scheduled immunizations. Ten days after the last immunization the rabbits were exsanguinated. Blood was incubated for $1 \mathrm{~h}$ at $30^{\circ} \mathrm{C}$. Following centrifugation at $1500 \mathrm{~g}$ for $20 \mathrm{~min}$, serum IgG antibodies were obtained at $20 \%$ saturation with sodium sulphate. After centrifugation at $1500 \mathrm{~g}$ for $30 \mathrm{~min}$, the pellet was dissolved in a phosphate buffer of $\mathrm{pH} 8.8$, 
dialysed for $15 \mathrm{~h}$ at $4^{\circ} \mathrm{C}$ with a phosphate buffer being changed four times and the IgG fraction was lyophilized.

Direct ELISA method (Engval and Perlman, 1971). A microtitre plate (Nunc $\left.{ }^{\circledR}\right)$ was coated with $1 \mu \mathrm{g} / \mathrm{ml}$ of antigen (pea protein extract or its tryptic hydrolysates DH 2.0 and 5.0) in $50 \mathrm{mM}$ carbonate buffer of $\mathrm{pH} 9.8$ and incubated overnight at $4^{\circ} \mathrm{C}$. After washing with TPBS $(10 \mathrm{mM}$ of PBS, $\mathrm{pH} 7.4$ with $0.5 \%$ of Tween 20$)$, residual free binding sites were blocked with $150 \mu 1 /$ well of $1.5 \%$ gelatine (G 9382, Sigma, Poznań, Poland) for $30 \mathrm{~min}$ at $25^{\circ} \mathrm{C}$. Next, the dilutions of rabbit blood serum (1:50 to 1:102400) samples were added to the antigen-coated and gelatineblocked well for $1 \mathrm{~h}$ at $37^{\circ} \mathrm{C}$. After washing, the plate was incubated for $1 \mathrm{~h}$ at $37^{\circ} \mathrm{C}$ with $100 \mu 1 /$ well of peroxidase-conjugated goat anti-rabbit immunoglobulin G (A 6154, Sigma, Poznań, Poland), followed by washing and addition of $o$ phenylene-diamine dihydrochloride (P 8287, Sigma, Poznań, Poland). After $30 \mathrm{~min}$ of incubation, $100 \mu \mathrm{l} / \mathrm{well}$ of $4 \mathrm{M}$ sulphuric acid were added to stop the reaction. Absorbance was read at $492 \mathrm{~nm}$ on an automatic plate reader (Reader 510, Organon Teknika, Brussels, Belgium).

Competitive ELISA method (Engval and Perlman, 1971). The microtitre plate (Nunc ${ }^{\circledR}$ ) was coated with $100 \mu \mathrm{l} /$ well of antigen (pea protein or its tryptic hydrolysates DH 2.0 and 5.0 ) in $50 \mathrm{mM}$ carbonate buffer at a $\mathrm{pH}$ of 9.8 and incubated overnight at $4^{\circ} \mathrm{C}$. After washing, residual free binding sites were blocked with $150 \mu \mathrm{l} /$ well of $15 \%$ gelatine (G 9382, Sigma, Poznań, Poland) for $30 \mathrm{~min}$ at $25^{\circ} \mathrm{C}$. Next, the solution of rabbit antibodies [ $(50 \mu \mathrm{l} /$ well diluted with PBS (1:12000) and the sample examined (50 $\mu 1 /$ well)] were added simultaneously to the antigen-coated and gelatine-blocked well for $1 \mathrm{~h}$ at $37^{\circ} \mathrm{C}$. After washing, the plate was incubated for $1 \mathrm{~h}$ at $37^{\circ} \mathrm{C}$ with $100 \mu \mathrm{l} /$ well of peroxidase-conjugated goat anti-rabbit immunoglobulin G (A 6154, Sigma, Poznań, Poland), followed by washing and addition of $o$-phenylene-diamine dihydrochloride (P 8287, Sigma, Poznań, Poland). After 30 min of incubation, $100 \mu \mathrm{l} /$ well of $4 \mathrm{M}$ sulphuric acid were added to stop the reaction. Absorbance was read at $492 \mathrm{~nm}$ on an automatic plate reader (teader 510, Organon Teknika, Brussels, Belgium).

Affinity chromatography. Sepharose 4B (column: $10 \times 2.5 \mathrm{~cm}$ ) was activated with bromine cyanide. $100 \mathrm{mg}$ of the rabbit immunoglobulin against the antigen (pea protein extract) was bound to the activated Sepharose 4B. Next, $60 \mathrm{mg}$ of antigens (tryptic pea protein hydrolysate DH 2.0 and DH 5.0) dissolved in $1 \mathrm{ml}$ of PBS (pH 7.4) were loaded on the top of the column and left for $12 \mathrm{~h}$ at $4^{\circ} \mathrm{C}$. The unbound antigens were washed out from the column with PBS until absorbance at $220 \mathrm{~nm}$ reached 0.02 . The bound antigens were released from the column with $0.1 \mathrm{M}$ glycine- $\mathrm{HCl}$ buffer $(\mathrm{pH} 2.8)$ at $0-2^{\circ} \mathrm{C}$. The fractions were immediately alkalized with carbonate buffer ( $\mathrm{pH} 8.2$ ), dialysed against distilled water at $4^{\circ} \mathrm{C}$, and lyophilized. 
SDS-PAGE electrophoresis. Polyacrylamide gel at a concentration of $15 \%$ and an acrylamide-to-methylenebisacrylamide ratio of 37:1 was prepared according to Laemmli (1970). The separation of proteins was carried out with TRIS-glycine buffer ( $\mathrm{pH} \mathrm{8.3)} \mathrm{and} \mathrm{a} \mathrm{voltage} \mathrm{drop} \mathrm{of} 40 \mathrm{~V} / \mathrm{cm}$ using a Flat Bed Apparatus FBE 300 (Pharmacia, Sweden). Proteins were stained with Coomassie brilliant blue R-250 and additionally glycoproteins were stained with Kit Pro-Q ${ }^{\mathrm{TM}}$ - Emerland 300 Glycoprotein Gel Kit (P-21855; Molecular Probes Inc. Eugene, OR, USA). The stained gels were scanned at $510 \mathrm{~nm}$ on a spectrophotometer (Specord M-40, Germany) with a scanner transport system.

The molecular weight of the protein bands was calculated from a standard curve prepared with Sigma standards (Mw range 6 500-205 000), using the KODAK 1D (3.5.4) programme.

Sequential analysis. The sequence analysis of the $\mathrm{N}$-terminal fragments of the antigens was performed by a gas-phase sequencer (Model 491, USA) (Gendel, 1998). Phenylhydantoin derivatives of amino acids were analysed by an integrated HPLC system (Microgradient Delivery System, Model 140 C, USA).

\section{RESULTS}

The protein content of pea seeds was 21.6\%. The SDS-PAGE electrophoresis of pea protein extract showed sixteen bands with molecular weights ranging from 10 to $50 \mathrm{kDa}$ (Figure 1). The maximum degree of

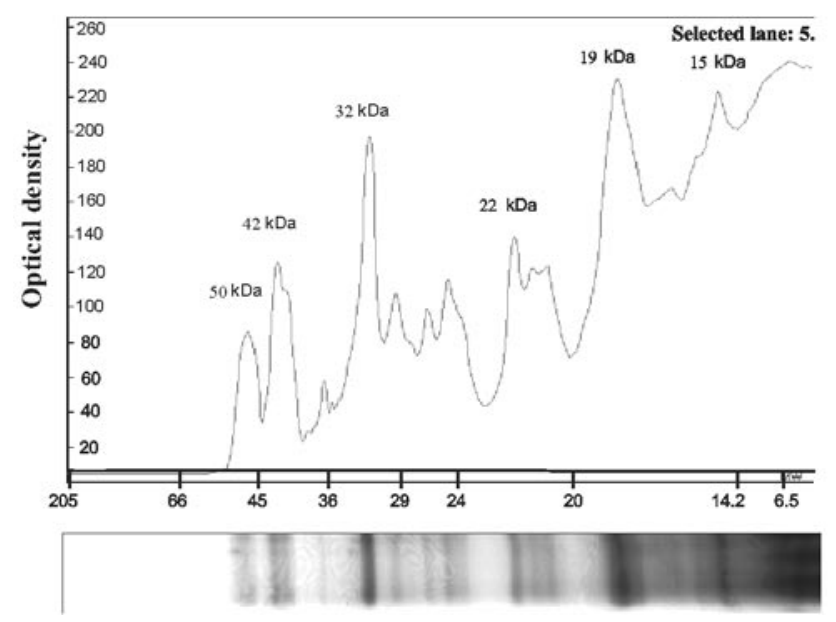

Figure 1. SDS-PAGE electrophoresis of pea protein extract 
hydrolysis (DH 5.0) of pea protein extract by trypsin was reached after about two h (Figure 2). The electrophoretic separations of trypsin hydrolysates showed the presence of three main fractions with molecular weights of 14, 17 and 20 $\mathrm{kDa}$. The $20 \mathrm{kDa}$ fraction dominated (Figure 3). The changes in polyclonal antibody titre during immunization of the rabbits are presented in Figure 4.

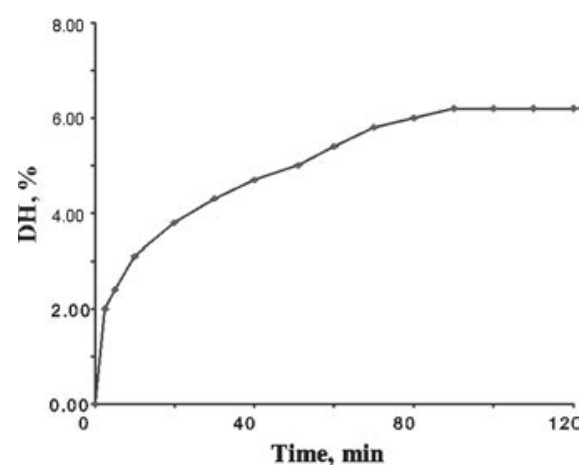

Figure 2. Kinetics of the hydrolysis of pea protein extract by trypsin

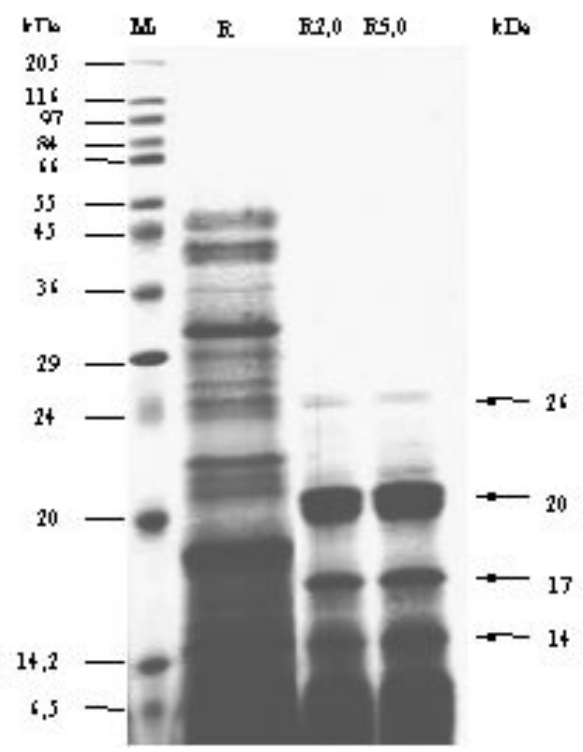

Figure 3. SDS-PAGE electrophoresis of pea protein extract and its trypsin hydrolysates (DH 2.0 and 5.0). Mw - markers, R -pea protein extract, R 2.0 and R 5.0 - trypsin hydrolysates with DH 2.0 and 5.0 


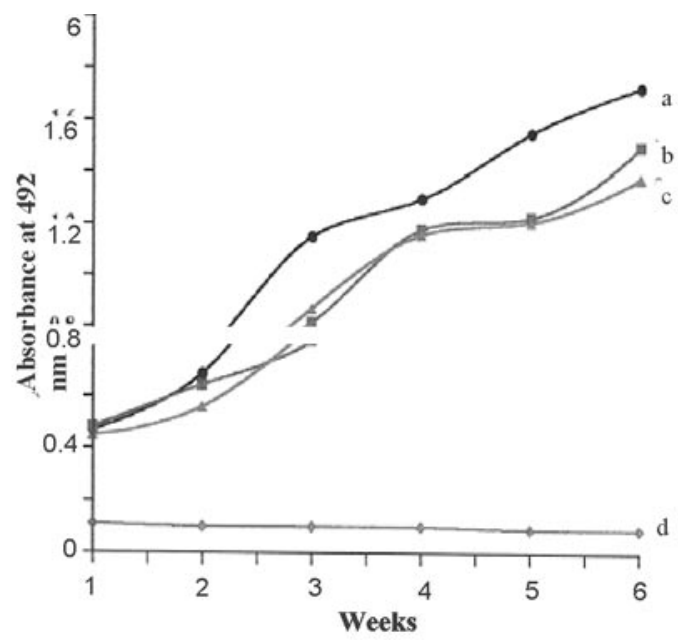

Figure 4. Changes of titre of polyclonal rabbit antibodies during immunization

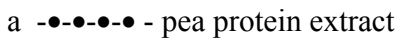

b -m-m-a- trypsin hydrolysate (DH 2.0) of pea protein extract

c $-\boldsymbol{\Delta}-\boldsymbol{\Delta}-\boldsymbol{\Delta}-\boldsymbol{\Delta}-$ trypsin hydrolysate (DH 5.0) of pea protein extract

Statistically significant differences in the increase of rabbit antibody titres were observed between the pea extract and its trypsin hydrolysates with DH 2.0 and 5.0. These results showed (Table 1) that the pea protein extract displays a stronger

Table 1. Antibody titres against the pea protein extracts and its trypsin hydrolysates with DH 2.0 and 5.0

\begin{tabular}{lc}
\hline Antigen & Antibody titre \\
\hline Pea protein extract & $1: 25600$ \\
Trypsin hydrolysate (DH 2.0) & $1: 6400$ \\
Trypsin hydrolysate (DH 5.0) & $1: 3200$ \\
\hline
\end{tabular}

immunogenic potential (1:25 600) than its trypsin hydrolysates with DH 2.0 (1:6 400) and DH 5.0 (1:3 200). The antigens were additionally characterized with the competitive ELISA test. This test enables determining the competition of antigens against the antibodies produced against pea protein extract (Figure 5). The results indicate that the pea protein extract was most strongly bound to the antibodies while the trypsin hydrolysates differed in competition in relation to antibodies (Figure 5). A higher affinity to the antibodies was shown by trypsin 


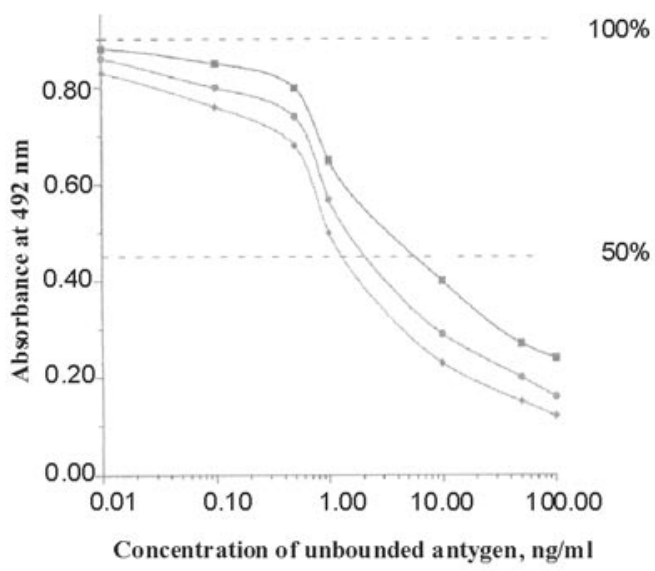

Figure 5. Compeptitive ELISA of pea protein and its hydrolysates

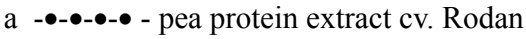

b -m-m-a- trypsin hydrolysate (DH 2.0) of pea protein extract cv. Rodan

c - $\boldsymbol{\Delta}$ - $\boldsymbol{\Delta}$ - $\boldsymbol{\Delta}$ - $\boldsymbol{\Delta}$ - trypsin hydrolysate (DH 5.0) of pea protein extract cv. Rodan

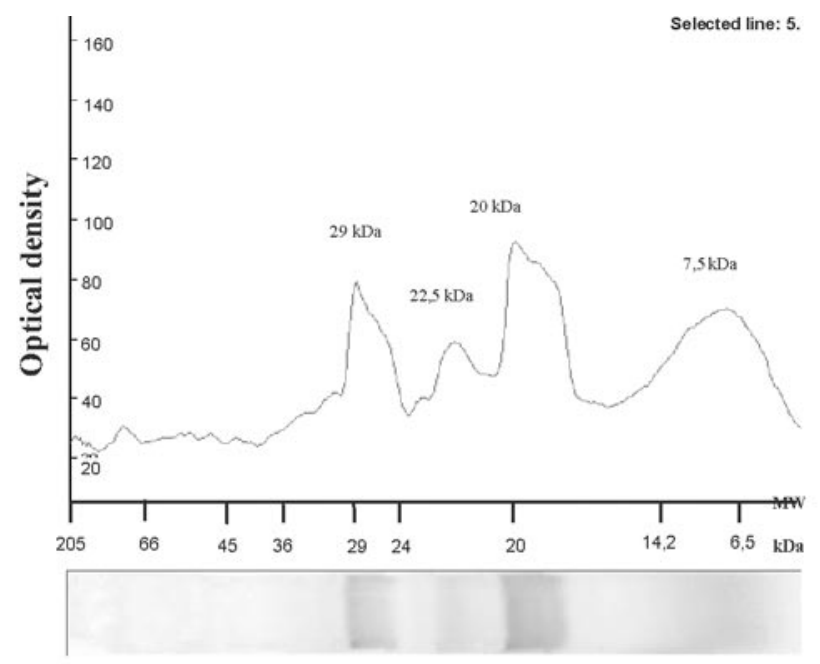

Figure 6. SDS-PAGE electrophoresis of antigen fraction of pea protein extract

hydrolysates with DH 2.0 than DH 5.0. The electrophoretic characterization of the antigens is presented in Figures 6 to 8. Three main bands with molecular weights of 7.5, 20.0 and $22.5 \mathrm{kDa}$ were observed on all electrophoregrams. An 


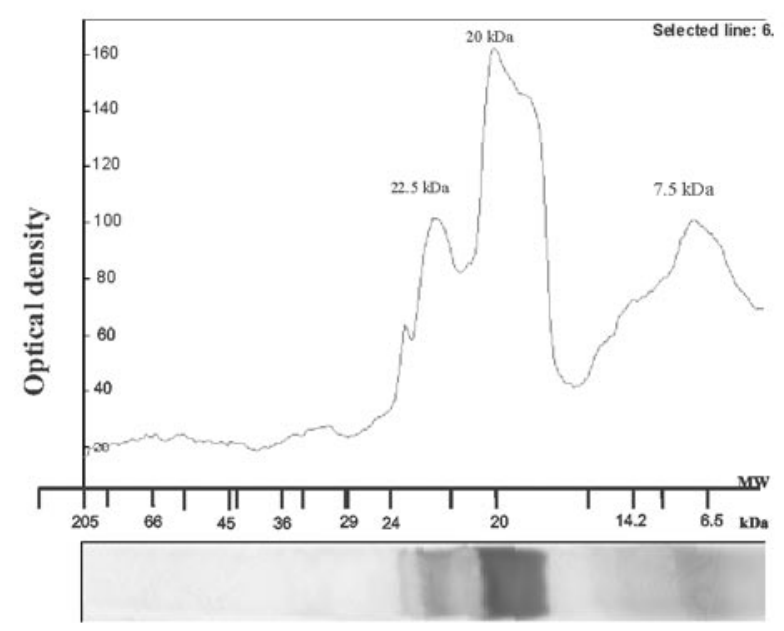

Figure 7. SDS-PAGE electrophoresis of antigen fraction of trypsin hydrolysate DH 2.0
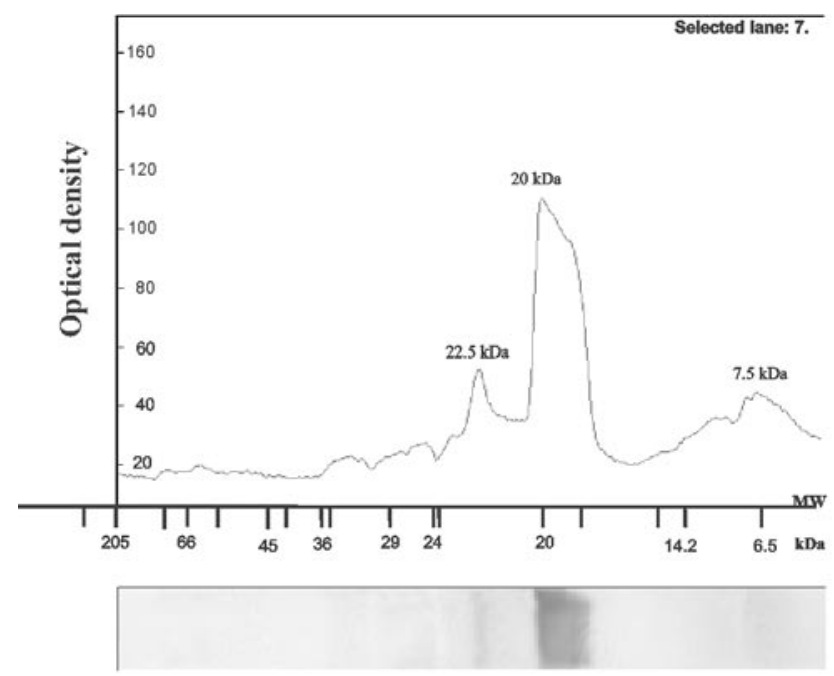

Figure 8. SDS-PAGE electrophoresis of antigen fraction of trypsin hydrolysate DH 5.0

additional band with a molecular weight of $29.0 \mathrm{kDa}$ was found in the pea protein extract. The dominant antigen in all cases was in the band with a molecular weight of $20.0 \mathrm{kDa}$. The N-terminal of this antigen was found to have the sequence ThrGlu-Thr-Thr-Ser-Phe-Leu-Ile-Thr-Lys. In addition, it was shown that this antigen is a glycoprotein with $\mathrm{pH}_{1} 4.44$ (Figures 9 and 10) (Hefle, 1996). 


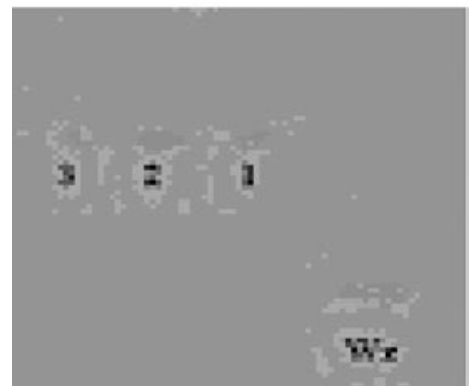

Figure 9. SDS-PAGE electrophoresis of antigen glycoproteins with molecular weights: 1-7.5 kDa, 2-20.0 kDa, 3-22.5 kDa, Mw - marker (44 kDa)

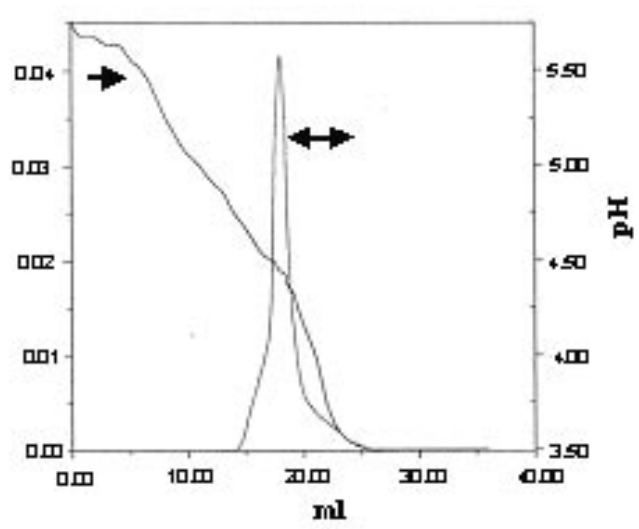

Figure 10. Diagram of isoelectric $\mathrm{pH}_{\mathrm{I}}$ of antigen glycoprotein $20.0 \mathrm{kDa}$

$\rightarrow$ - gradient of $\mathrm{pH}$

$\longleftrightarrow$ - fraction of antigen glycoprotein $20 \mathrm{kDa}$

\section{DISCUSSION}

The protein content in pea seeds depends on both the botanical variety of the pea and the abiotic conditions of the cropping. Gueguen and Barbol (1988) reported that the differences in the ratio of pea albumins to pea globulins range from 12 to $38 \%$ of total proteins. These facts may suggest that the immunogenic potential of pea proteins and their enzymatic hydrolysates can be different and dependent on the variety of pea. The protein content in pea seeds can influence enzymatic hydrolysis. Crevieu-Gabriel (1999) proved that the constituent proteins 
of feed peas (i.e. globulins, albumins, insolubles) and their subfractions are highly variable in terms of their digestibilities. Protein structure, including hydrophobicity, glycosylation, beta-sheets, compact tertiary structure and disulphide bonds, can have negative a impact on protein hydrolysis. From the nutritional point of view, the immunogenic and allergenic potential of pea proteins is very important. Unfortunately, pea proteins are allergenic. In particular, the major potential allergens from pea are vicilin and convicilin (Sanchez-Monge et al., 2004). In the present study it was found that the pea protein extract was a stronger immunogen than its trypsin hydrolysates. That means that enzymatic hydrolysis reduces rather than eliminates the immunogenicity of pea proteins. These results seem to confirm the view of Ena et al. (1985) that the immunogenic potential of proteins and their hydrolysates depends not only on the amino acid sequences of the epitopes but also on their molecular weight and conformation. Our results also suggest that the cause of this phenomenon was the degradation of the antigen fraction with a molecular weight of $20.0 \mathrm{kDa}$. However, the difference in the immunogenic potential of the trypsin hydrolysates with DH 2.0 and 5.0 was probably caused by different amounts of antigens in the trypsin hydrolysates. Sanchez-Monge et al. (2004) proved that pea vicilin and one of its proteolytic fragments $(32 \mathrm{kDa})$, reacted with more than half of the individual sera tested. Additional proteolytic subnits of vicilin $(36,16$ and $13 \mathrm{kDa}$ ) bound $\mathrm{IgE}$ from approximately $20 \%$ of the sera. Our results proved that the fraction with a molecular weight of $20 \mathrm{kDa}$ had the greatest antigenic potential, suggesting that this antigen could have allergenic properties. An additional argument for this suggestion can be the fact that this antigen is a glycoprotein with an isoelectric $\mathrm{pH}_{\mathrm{I}}$ of 4.44 (Hefle, 1996). According to Ueda and Ogawa (1999), many glycoproteins have the allergenic properties.

\section{CONCLUSIONS}

Data obtained in this study demonstrated the presence of four antigens in the protein extract of pea cv. Rodan, and three antigens in its trypsin hydrolysates. Pea protein extract had a higher immunogenic potential than its trypsin hydrolysates. Moreover, the trypsin hydrolysates of pea protein differed in their immunogenic potentials. Thus, our results seem to confirm the thesis that the immunogenic potential of proteins and peptides is determined not only by specific amino acid sequences but also by their molecular weights. The glycoprotein fraction with a molecular weight of $20 \mathrm{kDa}$ was the most immunogenic, which confirms the high immunogenic potential of glycoproteins. Finally, it can be assumed that pea proteins and their enzymatic hydrolysates are the potential allergens for humans and animals. 


\section{REFERENCES}

Adler-Nissen J., 1979. Determination of the degree of hydrolysis of food protein hydrolyzates by trinitrobenzenesulfonic acid. J. Agr. Food Chem. 27, 1256-1260

Bradford M. M., 1976. A rapid and sensitive method for the quantitation of microgram quantities of protein utilizing the principle of protein-dye binding. Anal. Biochem. 72, 248-254

Crevieu-Gabriel I.,1999.Digestion des protéines végétales chez les monogastriques. Example des protéines de pois. INRA Prod. Anim. 12, 147-161

Ena J. M., Van Beresteijn E.C.H., Robben J. P. M., Schmidt D.G., 1995. Protein antigenicity reduction by fungal proteinases and a pepsin/pancreatin combination. J. Food Sci. 60, 104-110

Engval E., Perlman P., 1971. Enzyme-linked immunosorbent assay (ELISA). Quantitative assay of immunoglobulin G. Immunochemistry 3, 871-876

Gendel S.M., 1998. Sequence database for assessing the potential allergenicity of proteins used in transgenic foods. Adv. Food Nutr. Res. 42, 63-91

Gueguen J., Barbol J., 1988. Quantitative and qualitative variability of pea (Pisum sativum) protein composition. J. Sci. Food Agr. 42, 209-224

Hajos G., Elias I., Halask A., 1988. Metionine enrichment of milk protein by enzymatic peptide modification. J. Food Sci. 53, 739-742

Hayakawa K., Linko Y.-Y., Linko P., 1999. Mechanism and control of food allergy. Lebensm.-Wiss. Technol. 32, 1-11

Hefle S., 1996. The chemistry and biology of food allergens. Food Technol. 50, 86-92

Laemmli U.K., 1970. Cleavage of structural proteins during the assembly of the head bacteriophage T 4. Nature 227, 680-685

McLeester R.C., Hall T.C., Sun S. M., Bliss F.A., 1973. Comparison of globulin proteins from Phaseolus vulgaris with those from Vicia faba. Phytochemistry 2, 85-93

Sanchez-Monge R., Lopez-Torrejon G., Pascual C.Y., Varela J., Martin-Esteban M., Salcedo G., 2004. Vicilin and convicilin are potential major allergens from pea. Clin. Exp. Allergy 34, 17471753

Ueda H., Ogawa H., 1999. Glycobiology of the plant glycoprotein epitop: structure, immunogenicity and allergenicity of plant glycotypes. Trends Glycosci. Glycotechnol. 11, 413-428

Wang T.L., Domoney C., Hedley L., Casey R., Grusak M.A., 2003. Can we improve the nutritional quality of legume seeds? Plant Physiol. 131, 886-891

Wensing M., Knulst A.C., Piersma S., O’Kane E.F., Koppelman S.J., 2003. Patients with anaphylaxis to pea can have peanut allergy caused by cross-reactive IgE to vicilin (Ara h 1). J. Allerg. Clin. Immunol. 11, 420-424 